\title{
George S V Wills and the Westminster College of Chemistry and Pharmacy: A Chapter in Pharmaceutical Education in Great Britain
}

\author{
FREDERICK KURZER*
}

\begin{abstract}
Introduction
The history of pharmacy in Britain during the nineteenth and twentieth centuries was shaped by two main influences, namely the advancement of the pharmaceutical sciences, and the efforts of its practitioners to raise their calling to the rank of a recognized corporate profession. ${ }^{1}$

The work of the chemist and druggist—the future pharmacist—was an unusually responsible employment in that it supplied the community with medicines and drugs, and handled poisonous substances both for domestic and agricultural use. For the protection of the public it was desirable that chemists and druggists should possess a competent knowledge of their business, as evidenced by a recognized qualification. Thus the practice of pharmacy was gradually regulated by legislation through successive Acts of Parliament; instances of technical uncertainties or questions of professional conflict often led to decisions being sought in the Courts of Law.

On more than one occasion the chemists and druggists had to defend their territory from threatened or actual incursions, both from above by the apothecaries and medical practitioners, and from below by general dealers and warehousemen. These interlocking scientific, educational, social and legal aspects have given the history of pharmacy a many-facetted and occasionally somewhat turbulent character, with financial and political overtones possibly more prominent than those prevailing in other scientific disciplines.

The practice of pharmacy was gradually elevated from the rank of an occupation to that of a profession, particularly by the institution of a regulating body, the Pharmaceutical Society of Great Britain, and the introduction of qualifying examinations to ensure the professional competence of candidates entering the ranks of its registered members.

(C) Frederick Kurzer 2007

*Frederick Kurzer, PhD, DSc, Royal Free Hospital School of Medicine, London NW3 2PF, UK.

${ }^{1} \mathrm{~J}$ G L Burnby and D A Hutton, A guide to sources in pharmaceutical history, London, British Society for the History of Pharmacy, 1990; A C Wootton, Chronicles of pharmacy, with a bibliography, London, Macmillan, 1810; Charles H LaWall, Four thousand years of pharmacy: the curious lore of drugs and medicines, Garden City, NY, Garden City Publishing Co., 1927; Edward Kremers, Kremers and Urdang's history of pharmacy, Philadelphia, Lippincott, 1976;

Jacob Bell and Theophilus Redwood, Historical sketch of the progress of pharmacy in Great Britain, London, Pharmaceutical Society of Great Britain, 1880; Royal Pharmaceutical Society of Great Britain, Centenary commemoration, 15 April 1941, London, Pharmaceutical Press, 1941; Leslie G Matthews, History of pharmacy in Britain, Edinburgh and London, E \& S Livingstone, 1962; S W F Holloway, The Royal Pharmaceutical Society of Great Britain 1841-1991: a political and social history, London, Pharmaceutical Press, 1991; Stuart Anderson (ed.), Making medicines: a brief history of pharmacy and pharmaceuticals, London and Chicago, Pharmaceutical Press, 2005.
\end{abstract}




\section{Frederick Kurzer}

The ensuing need for training facilities was met, in the late and immediate post-Victorian era, to a considerable degree by the emergence of private schools of pharmacy, which were specially geared to preparing aspiring pharmacists for their qualifying examination. Amongst these, the Westminster College of Chemistry and Pharmacy was arguably the most prominent, successful and enduring example. An examination of its origin and its progress over a period of nearly seventy years (1874-42) provides an interesting insight into a significant aspect of this phase of pharmaceutical education that has previously received little attention. ${ }^{2}$

\section{The Pharmaceutical Society of Great Britain}

A long-standing rivalry had existed between the Apothecaries (incorporated as a City company in 1617 , and specially licensed by charter since 1748$)^{3}$ and the chemists and druggists, who remained as yet unorganized. It led to repeated attempts of the former to gain exclusive control of the distribution of medicines to the public. Thus, when their proposed Parliamentary Bill of 1815 threatened to prohibit the practice of pharmacy to "uncertificated" persons, the chemists and druggists succeeded only narrowly, by concerted protests, to have the fatal clause withdrawn before the Bill was enacted.

Twenty-five years later, the Apothecaries attempted once again to secure a hegemony over the chemists and druggists: they proclaimed (not without truth) that unlike themselves, chemists were not required to pass any public examination, nor hold any approved certificates as dispensers of medicines and suppliers of poisons and dangerous drugs. They introduced a Bill into Parliament that would, in effect, empower them to oversee the business of a set of competitors whom they regarded as their inferiors. ${ }^{4}$ Once again, the proposals were strenuously opposed by their intended targets, who found support both inside and outside Parliament, eventually preventing the Bill from reaching the Statute Book. These episodes did not fail to impress on the chemists and druggists the vulnerability of their position, and the urgent need to secure official recognition of their place within the medical hierarchy.

The decisive step in protecting the future independence of the chemists and druggists was the foundation in 1841 of the Pharmaceutical Society of Great Britain, largely by the initiative of several leading spirits, foremost amongst them Jacob Bell and William Allen. ${ }^{5}$ Its royal charter (1843) identified the Society's chief objectives as the advancement

\footnotetext{
${ }^{2}$ M P Earles, 'The pharmacy schools of the nineteenth century', in Frederick N L Poynter (ed.), The evolution of pharmacy in Britain, London, Pitman Medical Publishing, 1965, pp. 79-95, on pp. 88-9.

${ }^{3}$ C R B Barrett, The history of the Society of Apothecaries of London, London, Elliot Stock, 1905; W S C Copeman, The Worshipful Society of Apothecaries of London: a history 1617-1967, London, Worshipful Society of Apothecaries, 1980; Penelope Hunting, A history of the Society of Apothecaries, London, Society of Apothecaries, 1998.
}

\footnotetext{
${ }^{4} \mathrm{~A}$ Bill to amend the laws relating to the medical profession of Great Britain and Ireland, introduced by Benjamin Hawes. For a summary, see The Chemist, 1840, 1: 373-9.

${ }^{5}$ Jacob Bell (1810-1859), MP, architect and co-founder of the Pharmaceutical Society, and editor of the Pharmaceutical Journal for eighteen years, Oxford Dictionary of National Biography, 2004 (hereafter $O D N B$ ), vol. 4, pp. 943-5; Willian Allen (1770-1843), FRS (1807), scientist and philanthropist, lecturer at Guy's Hospital (1802-26), first President of the Pharmaceutical Society (1841-43), ODNB, vol. 1, pp. 833-5.
} 


\section{George S V Wills and Pharmaceutical Education in Great Britain}

of chemistry and pharmacy, the promotion of a uniform system of education for its practitioners, and the legal protection of those who carried on this calling. In return, the public could expect greater safety and more expert service by dealing with properly qualified professionals.

The young Society pursued these aims vigorously, and consolidated its position by acquiring London premises, laying the foundations of a School of Pharmacy, and by publishing its official periodical, the mark of a reputable scientific or professional institution. ${ }^{6}$ As a result of these exertions, the chemists and druggists had the satisfaction of finding themselves officially listed in the Census of 1861 among the professional class, as "persons who render direct service to mankind", while manufacturing chemists were still assigned to the industrial class, alongside workers and artisans. ${ }^{7}$

Although the chemists and druggists had been motivated largely by external pressures to rally to the defence of their calling, they were not alone in their concern for their professional status: other professions desired to raise their respectability in the eyes of the public by improved standards of education and competence of their members. One effectual measure of achieving this was to replace or supplement the traditional admission to their ranks by apprenticeship or pupillage with formal qualifying examinations, preferably in conjunction with approved courses of study. ${ }^{8}$

Thus the Law Society, founded in 1827, began to regulate the training of solicitors by a system of examinations inaugurated in 1836. The measure had the incidental beneficial effect of guarding the profession against incursions from outsiders, such as unqualified legal advisers, general agents, and accountants, from which it was apt to suffer. ${ }^{9}$ In $1847-8$, the Institute of Actuaries and the Institution of Mechanical Engineers were founded as professional organizations and examining bodies. ${ }^{10}$ Even the physicians and surgeons, though members of old-established and respected professions, still lacked a consistent system of recognizable qualifications: this was now introduced and administered by their respective Royal Colleges by a stricter examination regime. ${ }^{11}$ From the mid-century, the number of associations conferring vocational qualifications proliferated, reaching a total of 136 in England and Wales by the 1960s; they earned increasing public respect as guardians of professional competence and conduct. ${ }^{12}$

\footnotetext{
${ }^{6}$ The Pharmaceutical Journal and Transactions, 1842-1895; continued as The Pharmaceutical Journal, 1895-1908; continued as The Pharmaceutical Journal and Pharmacist, 1909-1932; continued as The Pharmaceutical Journal, 1933 to date.

${ }^{7}$ Census returns for Great Britain for 1861 , PP 1863, LIII, p. 231.

${ }^{8} \mathrm{~W}$ J Reader, Professional men: the rise of the professional classes in nineteenth-century England, London, Weidenfeld \& Nicolson, 1966, esp. ch. 9; Geoffrey Millerson, The qualifying associations: a study in professionalization, London, Routledge \& Paul, Humanities Press, 1964, ch. 5, pp. 120-47.

${ }^{9}$ David Sugarman, A brief history of the Law Society, London, The Law Society, 1995, pp. 8-13; Albert Gibson and Arthur Weldon, How to become
}

a solicitor, 5th ed., London, The Law Notes Publishing Office, 1937.

${ }^{10} \mathrm{R}$ C Simmonds, The Institute of Actuaries 1848-1948, London, Cambridge University Press, 1948, pp. 3-36; Robert Parsons, A history of the Institution of Mechanical Engineers, 1847-1947, Centenary Memorial Volume, London, 1947, pp. $47,61,69$.

${ }^{11}$ Charles E Newman, The evolution of medical education in the nineteenth century, London, Oxford University Press, 1957. See also Reader, op. cit., note 8 above, pp. 16-21.

${ }^{12}$ A list of "qualifying associations" (with dates of their foundation, incorporation and introduction of examinations, together with membership size and grades) has been compiled by Millerson, see note 8 above, pp. 222-45. 


\section{Frederick Kurzer}

The foundation year of the Pharmaceutical Society also marked the establishment of the Chemical Society by the practitioners of chemistry as teachers, manufacturers, analysts, and researchers. ${ }^{13}$ Its declared aims were purely academic, being "the general advancement of chemical science by the discussion and publication of new discoveries, and the interchange of information respecting them", and by the setting up of a library. The Society imposed no restrictions to applicants for admission beyond a declared interest in chemistry, and the personal recommendation of two (later three) of its Fellows. It served a vastly smaller and slower-growing membership than its pharmaceutical sister-institution, ${ }^{14}$ but future developments were already foreshadowed in the wording of its royal charter (1848) which recognized:

the general advancement of chemical science as ultimately connected with the prosperity of the manufactures of the United Kingdom ... and [its importance] for a more extended and economical application of the industrial resources and sanatory $[s i c]$ conditions of the community. ${ }^{15}$

With the widening employment of chemists in industry, education and local authorities, a need for a stricter institutionalization of the profession was felt within the Society, but was eventually met by the creation, in 1877, of a separate body, the Institute of Chemistry. ${ }^{16}$ It fostered the general interests of the profession of chemistry, and the protection of the public by ensuring that "chemists were duly qualified for the proper discharge of their duties". Accordingly, it acted as an examining body, and its grades of associateship and fellowship (AIC, FIC) were accepted by employers as alternatives to a university degree in chemistry.

\section{The Apprenticeship}

Chemists and druggists had traditionally been admitted to their calling by serving an apprenticeship of up to six years in a chemist's shop. Although such a route may be adequate for learning an artisan's trade, it was clearly no longer a satisfactory method of entry into a profession that required, in addition to practical competence, a sound knowledge of much specialist information. Under this old system, the training of the pharmaceutical apprentice was indeed a matter of some chance depending on the good will and competence of the master, and the style and extent of his trade. It was only in the busier shops of the larger towns that a young beginner had the opportunity of thoroughly learning the art of dispensing and receiving an all-round training. Neglect and ill-use were

\footnotetext{
${ }^{13}$ Chemical Society, The jubilee of the Chemical Society of London, London, 1896; Tom Sidney Moore and James C Philip, The Chemical Society, 1841-1941: a historical review, London, Chemical Society, 1947.

${ }^{14}$ Some comparable figures are: Pharmaceutical Society: 1841: 800; 1842: 2000; 1941: 25,000; 1951: 27,000; 1962: 28,000. Chemical Society: 1841: 77; 1846: 185; 1850: 271; 1860: 323; 1951: 9,000.

${ }^{15}$ The British Council, Scientific and learned societies of Great Britain, London, George Allen \& Unwin, 1951, p. 53.
}

\footnotetext{
${ }^{16}$ Colin A Russell, Science and social change: 1700-1900, London, Macmillan, 1983; Colin A Russell, Noel G Coley and Gerrylynn K Roberts, Chemists by profession: the origins and rise of the Royal Institute of Chemistry, Milton Keynes, Open University Press in association with the Institute of Chemistry, 1977; Richard B Pilcher, The Institute of Chemistry of Great Britain and Ireland: history of the Institute 1977-1914, London, Institute of Chemistry, 1914.
} 


\section{George S V Wills and Pharmaceutical Education in Great Britain}

not unknown: thus the future eminent chemist Edward Frankland, who served a sixyear apprenticeship in a chemist shop in the small provincial market-town of Lancaster, lamented later the "six wasted years of unprofitable labour and servitude" that he had endured. ${ }^{17}$ His master had taught him nothing, and such knowledge as he was able to gather was the result of his own curiosity. ${ }^{18}$ Even under so enlightened a proprietor as William Allen of the highly reputable pharmacy in Plough Court, City of London, the work ethos during the early nineteenth century was uncompromisingly severe. ${ }^{19}$

More cheerful but still sobering experiences were recollected by a pharmacist who had completed his apprenticeship in the 1890s in an obviously superior establishment, which kept four or five apprentices of ascending seniority. They performed increasingly responsible tasks, from the humble beginner's duties of tidying the shop and running errands, to the intermediate ranks preparing tinctures, extracts and galenicals, eventually graduating to the dignity of the dispenser's counter. Working hours were long, discipline strict, and sober deportment and appearance was insisted on. The proprietor, who divided his time between the front counter, his account books and business correspondence, did not pretend to attend to the training of his apprentices, who picked up their knowledge by practice, and from one another as best they could. ${ }^{20}$

A critical analysis of the reminiscences of a cross-section of British pharmacists who were active during the first half of the twentieth century confirms the diversity of the quality of their apprentice years, and incidentally gives some first-hand insight into the problems, financial and vocational, faced by the principals in running their business, which necessarily affected the progress and welfare of their apprentices. ${ }^{21}$

\section{Chemist by Examination}

Shortly after its foundation in 1841 , the Pharmaceutical Society established a School of Pharmacy at its headquarters at 17 Bloomsbury Square, with a staff of three professors (of pharmacy, chemistry and materia medica) and the provision of some teaching laboratories, for the preparation of candidates for its qualifying examinations. Passing the "Minor" examination (the title of which belied its comprehensive coverage of chemistry, botany, materia medica, pharmacy and dispensing) entitled the successful entrant to the style of

\footnotetext{
${ }^{17}$ Sir Edward Frankland (1825-1899), FRS (1853), ODNB, vol. 20, pp. 763-70; Edward Frankland, Sketches from the life of Edward Frankland, edited and concluded by his two daughters MNW and SJC, London, Spottiswood, 1902, pp. 20-36, esp. pp. 21, 23.

${ }^{18} \mathrm{C}$ A Russell, in reassessing Frankland's bitter reminiscences (set down some fifty years after the event) suggests that Frankland derived in fact greater advantages from the discipline and experience of his apprenticeship than he realized or was prepared to admit, but concedes that exploitation and neglect of apprentices was by no means uncommon in Victorian times. See Colin A Russell, Lancastrian chemist: the early years of Sir Edward Frankland, Milton Keynes, Open University Press, 1986; idem,
}

Edward Frankland: chemistry, controversy and conspiracy in Victorian England, Cambridge University Press, 1996.

${ }^{19}$ Ernest Cripps, Plough Court: the story of a notable pharmacy, 1715-1927, London, Allen \& Hanburys, 1927, pp. 31-4.

${ }^{20}$ Anon., 'Apprenticeship', Chemist and Druggist, 1932, 116: 63

${ }^{21}$ Stuart Anderson, 'Comunity pharmacy in Great Britain: mediation at the boundary between professional and lay care, 1920 to 1995 ', in M Gijswijt-Hofstra, G M Van Heteren and E M Tansey (eds), Biographies of remedies: drugs, medicines and contraceptives in Dutch and Anglo-American healing cultures, Amsterdam, Rodopi, 2002, pp. 75-97. 


\section{Frederick Kurzer}

"Chemist and Druggist", official registration with the Society, and the right to conduct a pharmaceutical business. The "Major" examination, which aimed at the consolidation of the scientific core subjects, led to the grander title of Pharmaceutical Chemist $(\mathrm{PhC})$.

During the early phase of this teaching project, alternative opportunities of receiving systematic instruction in scientific subjects were meagre. ${ }^{22}$ Such teaching as was available was usually limited to lectures, unsupported by practical work performed by the student. Science courses, albeit of varying quality, were offered by the recently conceived Mechanical Institutes, ${ }^{23}$ and elementary chemistry appeared on the syllabuses of the teaching hospitals of University College and King's College, London, and the Scottish universities, generally as part of the medical curriculum.

The first serious scheme of systematic instruction in a scientific discipline was realized with the foundation of the Royal College of Chemistry in $1845 .{ }^{24}$ By the active support of the Prince Consort (himself a temporary student of chemistry in his university days), the College secured the services, as its professor and director, of the future eminent German chemist A W Hofmann, then a young man of twenty-seven, who guided its fortunes for the next twenty years. ${ }^{25}$ As a pupil of Justus von Liebig, whose work and teaching was well known and admired in England, ${ }^{26}$ he introduced an academic teaching schedule in the image of the famous Giessen school, in which the student was thoroughly grounded in the principles of his science, and in the laboratory practice of chemical analysis. Dedicated students had the opportunity of taking part in Hofmann's ongoing researches in organic chemistry.

Between 1845 and 1853 (the year of its amalgamation with the Royal School of Mines) the College had been the training ground of 356 students, including some of the most distinguished future British academic chemists. ${ }^{27}$ The course was informal insofar as it did not lead to a degree or equivalent certification. It was also flexible, allowing the students the choice to leave early after having acquired a level of competence which they considered adequate for pursuing their future career as analysts, brewers, dyers, metallurgists, or teachers. A significant proportion (approximately 10 per cent) were pharmacists wishing to deepen their knowledge of chemistry, both for improving their examination prospects, and for enhancing their general proficiency.

The Pharmaceutical Society was anxious to encourage entrants to the profession to gain official recognition by way of its examinations, but the completion of a plain apprenticeship

\footnotetext{
${ }^{22}$ For a general account of English scientific education and institutions in the nineteenth century, see D S L Cardwell, The organisation of science in England, London, Heinemann, 1972.

${ }^{23} \mathrm{~J}$ W Hudson, History of adult education, London, Longman, Brown, Green \& Longmans, 1851, pp. 222-36; Thomas Kelly, George Birkbeck, pioneer of adult education, Liverpool, University Press, 1957.

${ }^{24}$ Russell, Coley and Roberts, op. cit., note 16 above, pp. 75-81; Gerrylynn K Roberts, 'The establishment of the Royal College of Chemistry: an investigation of the social context of early-Victorian chemistry', Hist. Stud. Phys. Sci., 1976, 7: 437-85.
}

\footnotetext{
${ }^{25}$ August Wilhelm Hofmann (1818-1892), $O D N B$, vol. 27, pp. 526-8.

${ }^{26}$ William H Brock, Justus von Liebig: the chemical gatekeeper, Cambridge University Press, 1997.

${ }^{27}$ Among other leading chemists, the

College's roll of past students listed four future Presidents of the Chemical Society, namely Warren de la Rue (1815-1889), ODNB, vol. 48, pp. 97-9; Sir Frederick Abel (1827-1902), ibid., vol. 1, pp. 62-3; William Odling (1829-1921), ibid., vol. 41, p. 498; Sir William Crookes (1832-1919), ibid., vol. 14 , pp. $398-400$.
} 


\section{George S V Wills and Pharmaceutical Education in Great Britain}

continued to be a sufficient qualification for owning or managing a retail pharmacy. The situation changed dramatically with the passing of the Pharmacy Act of $1868,{ }^{28}$ which laid down three main principles: the establishment of an official Register of qualified Pharmaceutical Chemists, of Chemists and Druggists, Assistants and Apprentices, and the restriction of such titles to duly registered persons; the necessity of all persons owning or managing a pharmaceutical business to pass the prescribed qualifying examination (those already established in their own shop being temporarily exempted from this requirement); and the conferment of the examining and registering functions on the Pharmaceutical Society.

The Act thus imposed on the rising generation of chemists and druggists a more uniform and stricter training than hitherto, and conferred on the Pharmaceutical Society considerable powers to enforce the measures, albeit under the ultimate supervision of a Committee of the Privy Council. Henceforth, the passing of the Society's qualifying examination was the aim of all young persons engaged in pharmacy. It required careful preparation hardly attainable by unsupervised private study, though occasionally attempted with success by able and determined candidates. A regular course of instruction was normally essential for a favourable outcome. The Society's own school, which had opened with a class of forty students in 1843, was, in spite of later expansion, unable to cope with the rising number of would-be students; adequate facilities were even less available in the provinces (except in Edinburgh). ${ }^{29}$

The situation stimulated the emergence of private teaching establishments specializing in preparing students for their pharmaceutical examinations. Evidence of a real need for such training centres was their steady spread; in the metropolis, the provinces, and Scotland their number increased from two in 1870, to five, seven and twenty-two in 1880, 1890, and 1900, respectively. ${ }^{30}$ Of these, the Westminster College of Chemistry and Pharmacy was by common consent the largest and most successful. It was founded in 1874 by G S V Wills, who guided its work as Principal for the next fifty years. Its surviving records and prospectuses, evidently more complete than those of similar establishments, and personal reminiscences concerning its Principal, convey an authentic and vivid picture of the busy life of a thriving private school of pharmacy of the period, and, with it, an impression of the substantial educational contribution of this sector as a whole. ${ }^{31}$

\footnotetext{
${ }^{28}$ An authoritative survey of all statutes enacted between 1853 and 1908 relating to the practice of pharmacy and the sale of poisonous substances, together with leading examples of case-law under these acts, is the treatise by W S Glyn-Jones, The law relating to poisons and pharmacy, with notes of cases, London, Butterworth, 1909.

${ }^{29}$ Initially, the School of the Pharmaceutical Society in Bloomsbury Square catered for only a very small proportion of the estimated 2000 to 3000 young men under the age of twenty who were engaged in the vocation. According to one source, on average eighty students attended its lectures annually, and only twenty-five could be accommodated in its laboratory at a time (see Holloway, op. cit., note 1 above, p. 110). There was, therefore, an obvious need for additional training facilities.
}

\footnotetext{
${ }^{30}$ Earles, op. cit., note 2 above, p. 90.

${ }^{31}$ A souvenir: the work of George $S V$ Wills and the Westminster College of Chemistry and Pharmacy (privately printed), 14 February 1899, 190 pages, illustrated, with an (unpaginated) Appendix of the names and addresses of above 800 past students in business in 1899 on their own account. This somewhat artless production contains a great deal of detail concerning Wills's career and character, amid the day-to-day work of the College. Prospectus and syllabus of the Westminster College of Chemistry and Pharmacy, London, SE, 1877 (Fifth Session); the same, a later version, 1901, with index, illustrated, 96 pages (bound in with Wills's Manual of practical analysis, see Appendix, no. 2).
} 


\section{Frederick Kurzer}

\section{George S V Wills and the Foundation of the Westminster College}

George Sampson Valentine Wills was born on 14 February 1849 in the village of Roade near Stony Stratford in the County of Buckinghamshire. ${ }^{32}$ Here his ancestors had for several generations worked as builders of some local consequence, his great-grandfather Sampson and grandfather George being active as stonemasons, and skilled in the construction of arched bridges and the repair of church buildings. Young Wills received his early education at the British School in Stony Stratford, and attended the town's Baptist Chapel and its Sunday school. It gave him the opportunity to learn to play the organ, and awakened a love of music that remained a source of pleasure throughout his life.

On leaving school, Wills attached himself for a time to a rural eccentric who practised "physic" amongst the country folk; he helped him in the manufacture of his simple remedies, and furthered his own fascination with plant and drug lore by reading as many books on these subjects as were within his reach. He was presently apprenticed (1866) to a chemist and druggist of the town: the shop changed hands twice in quick succession, but the resident apprentice Wills was each time taken over with the stock. The second of these masters, Mr Benjamin Bullus, fostered Wills's progress with benevolent care, and subsequently appointed him assistant in his new venture at Hookley Hill, Birmingham. Thereafter (from 1870), Wills worked in similar positions at Hay-on-Wye, Barrow-in-Furness, and Folkestone. Two years' private study while in this full-time employment enabled him to pass the all-important Minor examination of the Pharmaceutical Society.

He next secured the post, out of sixty applicants, of dispenser in the medical practice of C F DuPasquier, Apothecary to the Queen's Household. ${ }^{33}$ An obstacle arose when it was realized that Wills did not hold the Dispenser's Certificate of Apothecaries' Hall, which, though inferior in standard to his pharmacist's qualification, was in Dr DuPasquier's eyes, an essential prerequisite for royal service. Wills was confident of his ability to obtain the diploma without further preparation on his part. He offered to pass, within the next three days, the necessary examination (which was held weekly at that time). To DuPasquier's astonishment, he made good his promise and was duly confirmed in his new post. Its duties were apparently not onerous, affording a good deal of free time, which Wills soon put to good use. He remembered the plight of young colleagues he had met in the provinces, who had struggled to study for their qualifying examination but, lacking guidance, had usually failed. He resolved to help by devising a system of postal instruction that would direct their efforts to better effect. The enterprise was an instant success; for Wills it was the turning point of his career, showing him the path to his true vocation as a gifted teacher and educationalist.

The success of the postal scheme convinced Wills that there was similar scope for fulltime instruction. It gave him the confidence to resign his post with Dr DuPasquier, and inaugurate in October 1874 the Westminster College of Chemistry and Pharmacy in his

\footnotetext{
${ }^{32}$ The biographical details of Wills's early life are mostly gleaned from the souvenir volume (see note 31 above).

${ }^{33}$ Claudius Francis DuPasquier (1812-1897), FRCS (1859) combined a fashionable general practice at 4 Cleveland Row, adjoining St James's Palace,
}

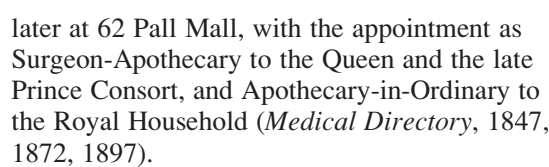
1872, 1897). 


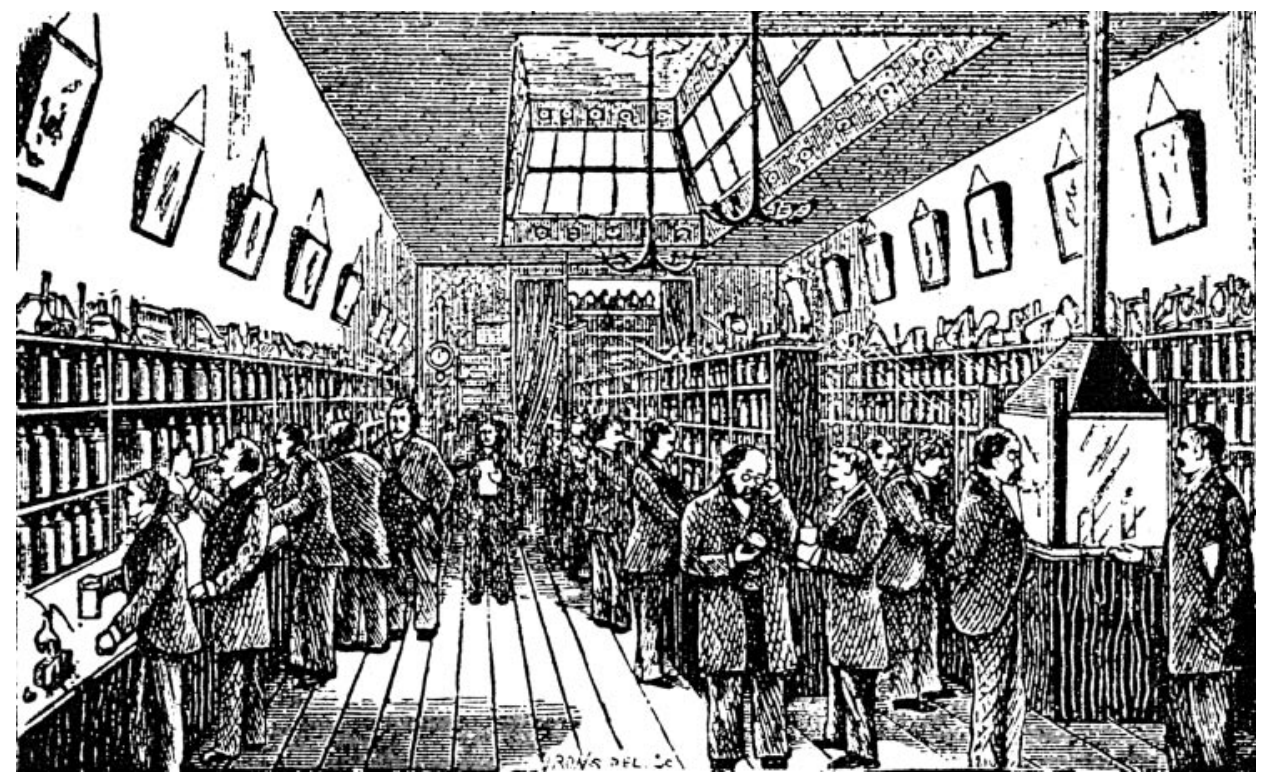

Figure 1: The chemical laboratory of Westminster College, at North Street, Kennington Road (c.1880). From A souvenir: the work of George $S V$ Wills and the Westminster College of Chemistry and Pharmacy, privately printed, 1899.

house at 133 St George's Road, Lambeth. At first, only two rooms were fitted up as laboratories, and the number of pupils was small, but soon one room after another had to be given over to teaching, until Wills was literally turned out of his home, and further accommodation had to be found in a pair of adjacent houses in nearby Lambeth Road. Continued growth of the College necessitated the transfer of some departments to two large halls in North Street, Kennington Road. An artist's impression of the chemical laboratory on this site is curiously reminiscent of the well-known print of Liebig's famous laboratory in Giessen, not least by the obvious maturity of many of the students (Figure 1).

Even these enlarged premises soon proved inadequate. When another move became unavoidable, Wills was fortunate in acquiring in 1882 the distinctive building of a defunct Baptist chapel in Trinity Street, Southwark (Figure 2). As the more affluent members of its congregation had left the crowded streets of Victorian inner London for the healthier and more pleasant suburbs, attendance at the chapel declined and led to its eventual closure and sale. In its new function, the nave became the main lecture hall, accommodating 100 students. The two lateral galleries were levelled, enclosed, and fitted up as a chemical laboratory with seventy-four work-places along one wall, and smaller rooms for practical work along the other.

\section{The Westminster College at Work}

In an establishment geared to meet clear educational targets efficiently and economically, the student was fully occupied all day in attending lectures and laboratory classes. The lecture hall (Figure 3) accommodated the entire student body, but for practical and 


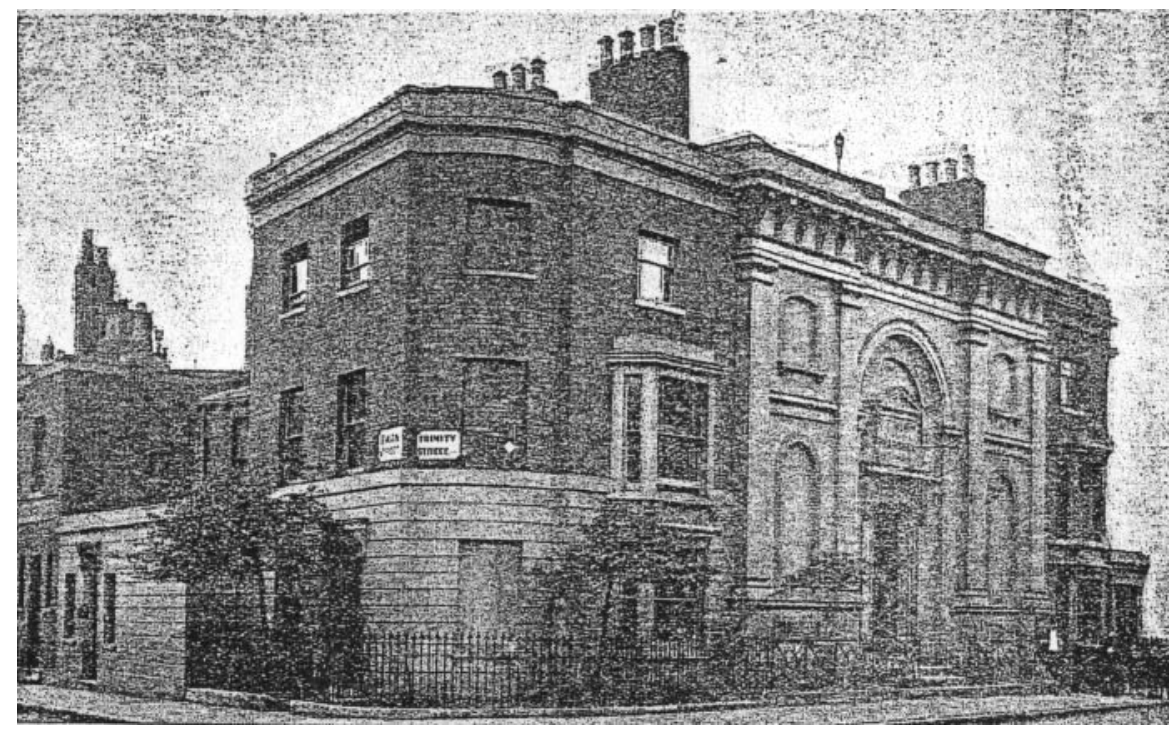

Figure 2: Westminster College of Chemistry and Pharmacy, Trinity Street, Southwark. The College building (formerly a chapel) is flanked by two private houses. From the Prospectus and syllabus of the Westminster College of Chemistry and Pharmacy, London, 1901.

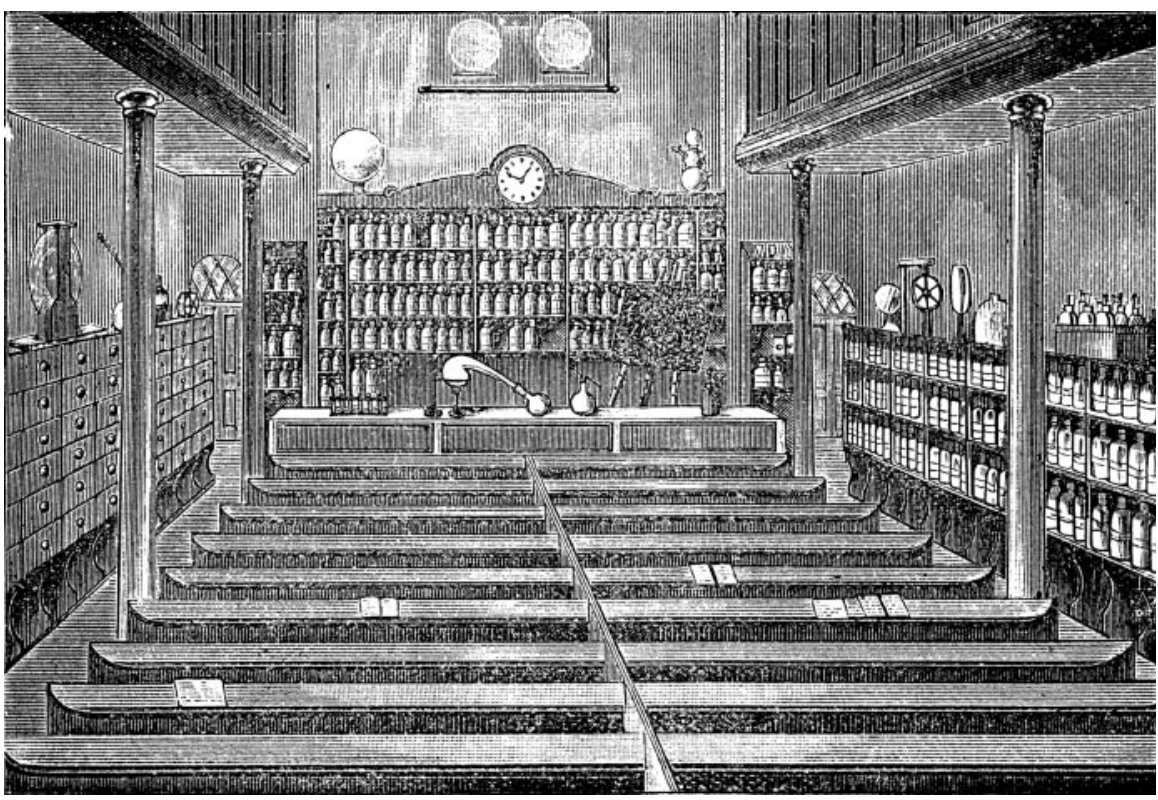

Figure 3: The lecture hall of Westminster College, formerly the nave of the Baptist chapel, was 41 feet long, by 31 feet wide, and 24 feet high. From A souvenir: the work of George $S$ V Wills and the Westminster College of Chemistry and Pharmacy, privately printed, 1899. 


\section{George S V Wills and Pharmaceutical Education in Great Britain}

special subjects, the class was split into five groups who participated in a dovetailed scheme that effected a full rotation twice each term. The system used the existing accommodation ingeniously to the best advantage and ensured that the students received maximum individual attention. On three evenings a week, part-time students kept the college open till 9 o'clock. The toil of dealing with the postal courses (see p. 494) continued behind the scene.

The cordial relations between teacher and student cultivated by the Principal notwithstanding, strict discipline reigned within the college as the essential condition for the student's progress. He was required to appear punctually in his assigned (numbered) place in the lecture room, the doors of which were firmly closed once a lecture had started. Casual behaviour was not tolerated and even more severe rules governed life in the laboratory to ensure the safety of the person and the preservation of the apparatus and equipment.

During the average college term of twelve or thirteen weeks, the student of the Minor course attended morning lectures in chemistry (30), botany and plant histology (25), materia medica and pharmacognosy (35), pharmacy (25), dispensing with prescription reading (35) and physics (12) (Figure 4). The afternoons were spent in the laboratory, chiefly in acquiring practice in qualitative (inorganic) and volumetric analysis. The interruption of these practical labours by the weekly formal Latin class may have afforded a change, but hardly a relaxation. The syllabus prescribed by the Pharmaceutical Society governed the course content and is reflected in the teaching manuals specially written by Wills for the use of his students. ${ }^{34}$ A great deal of factual information had to be absorbed and committed to memory, but was consolidated by the practical exercises. Instruction in dispensing included practice in deciphering doctors' prescriptions.

Weekly tests and end-of-term internal college examinations (at which medals and certificates could be won) ensured that students made regular progress and gained confidence. Under this regime they were usually ready to attempt the Minor examination after two terms' full-time work, but an even shorter course was occasionally sufficient for candidates who had had the good fortune to experience productive apprentice years under a competent and sympathetic master. The Major course, normally extending over two terms, concentrated on a more detailed coverage of organic chemistry, quantitative chemical analysis (with particular emphasis on the requirements of the British pharmacopoeia), and a more intimate acquaintance with materia medica. ${ }^{35}$

The cost of attending a full-time course was intrinsically moderate, but yet was no doubt beyond the means of many would-be students. The inclusive charge for the Minor course was, in 1899,8 guineas per term, reduced to 12 guineas for two terms, payable in advance. ${ }^{36}$ One payment of 15 guineas secured tuition "until qualified", but the open-endedness of this offer was not specified. ${ }^{37}$ The fee for the Major course was somewhat lower ( 6 guineas

\footnotetext{
${ }^{34}$ For a list of Wills's manuals and textbooks, see Appendix.

${ }^{35}$ The relative weight given to the individual subjects of both the Minor and Major courses is also reflected in the detailed contents of the postal courses (see Table 1).

${ }^{36}$ The guinea, though no longer coined after 1813 , continued as a unit of account, especially in medical,
}

legal and scholastic remuneration, and, being reckoned at $£ 11$ shilling, was an automatic device of raising charges by 5 per cent

${ }^{37}$ Prospectus, 1901, op. cit., note 31 above, p. 25; these figures must be multiplied by a factor of 40 to 50 to correspond to current price levels. 


\section{The Westminster College of Chemistry \& Pharmacy

Trinity Square, Borough, London, S.E.

Principal \& Founder :

Secretary:

Mr. GEORGE S. V. WILLS, F.L.S., \&c. Mr. J. E. WALDEN.

\section{TIME TABLE OF LECTURES.}

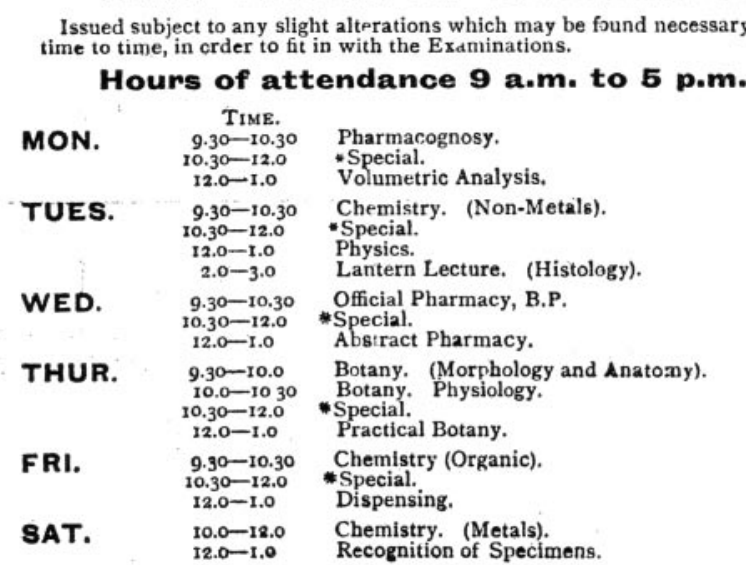

"Special Subjects.

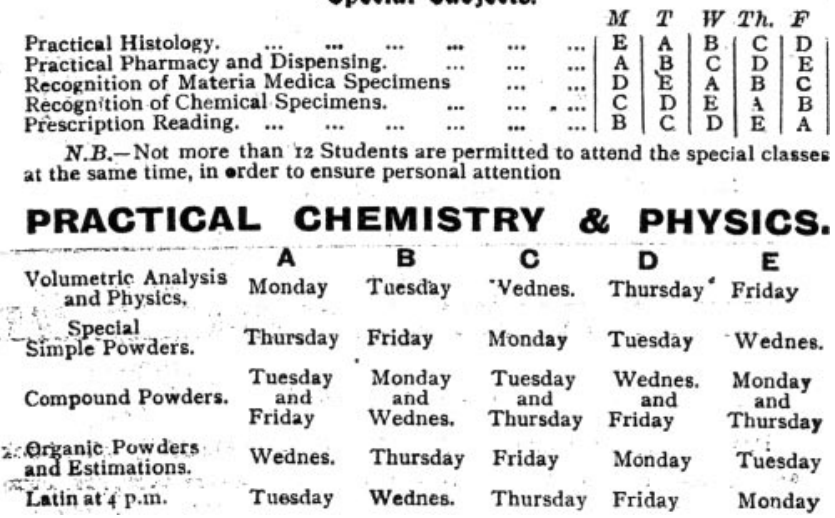

Figure 4: The College's timetable and schedule of lectures. From the Prospectus and syllabus of the Westminster College of Chemistry and Pharmacy, London, 1901.

per term). Students based outside London were offered accommodation with full board for 1 guinea per week in an approved local establishment for sixty resident pupils. The loss of potential earnings involved in full-time study was a serious deterrent to many candidates; they availed themselves of the College's evening classes-conducted on three nights 


\section{George S V Wills and Pharmaceutical Education in Great Britain}

per week, at the low cost of 1 guinea for one evening a week per term ${ }^{38}$ —or of the postal courses.

The great majority of the students clearly worked hard with a purpose, but there is no doubt that their Principal worked hardest of them all. During term, he lectured eight times a week to the Minor, and three times to the Major classes, usually exceeding the scheduled one-hour lecture time. He illustrated his lectures with demonstration experiments, and with large diagrams and charts drawn on rolls of calico wound on rollers, so that successive illustrations were moved into view. The botanical drawings were the work of Wills's eldest daughter Georgina, a trained artist and designer. According to the College records, Wills delivered his 10,000th lecture on 6 October 1909, an event that was noted in the pharmaceutical press ${ }^{39}$ and which attracted numerous messages of congratulation from former students.

In his teaching and administrative work, Wills was supported by his Associate, Henry Wootton (who subsequently started his own pharmaceutical school ${ }^{40}$ ), by a secretary responsible for the day-to-day management, and by two, sometimes three demonstrators, his son and his future son-in-law, Percival Woodnoth, amongst them; they were qualified pharmacists, who had usually distinguished themselves as medallists of the Pharmaceutical Society. ${ }^{41}$ When in later years, the course for the Assistant Dispenser's Certificate of Apothecaries' Hall was frequented by a majority of female students, the class was at times supervised by a lady-demonstrator.

\section{Research}

At this period, basic research in pharmacy was hardly a high priority. Investigations that were carried out in the Pharmaceutical Society's laboratory were mostly of an applied character, ${ }^{42}$ supplying data needed in the revision of successive editions of the British pharmacopoeia (first published in 1864; fourth edition 1898), in which the professors of the Society took an active part. A report of the Pharmaceutical Society's Council (1895) bestowed only faint praise on its own laboratory, referring to its research work with noticeable lack of enthusiasm as "on the whole satisfactory". According to a 1903 survey, experimental work was chiefly aimed at establishing approved methods of drug assay, laying down standards of purity, and suggesting improvements in current manufacturing processes. $^{43}$

${ }^{38}$ Prospectus, 1901, op. cit., note 31, p. 26.

${ }^{39}$ Chemist and Druggist, 1909, 75: 603.

${ }^{40}$ See note 63 below.

${ }^{41}$ Wills's son, H Sampson Wills, who had himself been a student at Westminster College, acted as a junior demonstrator until 1904. Qualifying in that year, he joined a local firm, Boilerine Ltd, as a research chemist, and was eventually appointed its Secretary (Chemist and Druggist, 1925, 103: 375). Percival Woodnoth, MPS, was the future Principal of the College.

${ }^{42}$ Wyndham R Dunstan (ed.), Chemical papers from the research laboratory of the Pharmaceutical
Society of London, London, Pharmaceutical Society of Great Britain, 1892. Most of the research contributions are by the editor, though there are papers by others.

${ }^{43}$ W Chattaway, Digest of researches and criticisms bearing on the revision of the British Pharmacopoeia 1898, prepared for the

Pharmacopoeia Committee of the General Council of Medical Education and Registration in the United Kingdom, London, Spottiswoode, 1903. The scope of the Pharmaceutical Society's researches of this period is illustrated by the request of the General Medical Council to its laboratory to determine to what extent the standardization of potent drugs can be performed 


\section{Frederick Kurzer}

Operating under tight financial restraints, the private schools were not able to divert resources from their primary training function to even the simplest experimental research. ${ }^{44}$ Even the well set-up Westminster College remained silent on this subject, when some of its more talented students might have benefited by participating in a modest experimental exercise, the outcome of which was not known in advance. The small technical library set aside for the use of students was "composed of books of reference for the various examinations", ${ }^{45}$ but it did not apparently subscribe to such periodicals as the Pharmaceutical Journal, or the Yearbook of Pharmacy, which would at least have drawn attention to current advances.

The intensive routine of the course work was occasionally relieved by visits to factories of major chemical or pharmaceutical manufacturers, presumably made possible by the good repute of the College and Wills's continued personal relationship with former pupils who had advanced to senior industrial positions. At the British Oxygen Company, for example, students watched the production of liquid oxygen from air by the Linde process, and the annealing and testing of the heavy steel cylinders, used in the storage of compressed gases. ${ }^{46}$ A group of fifty-two students visited the works of Burgoyne, Burbridge \& Co at East Ham, where they witnessed the large-scale production of pharmaceuticals. ${ }^{47}$ When Parke, Davis \& Co invited the College in 1916 to inspect their factories in Hounslow, women students outnumbered the men for the first time in Westminster's history. ${ }^{48}$ The parties were invariably led personally by Wills, who thanked the hosts at the conclusion of the visit in a courteous speech for the hospitality-educational and culinary-they had enjoyed. Periodic weekend excursions to the Royal Botanic Gardens at Kew gave the students opportunities to study medicinal plants in their natural habitat.

\section{The Success of Westminster College and its Repercussions}

The share of the Westminster College in the contemporary training of pharmacists was indeed impressive. After only three years' operation it was able to claim that, as the largest school of its kind in London, its students had achieved nearly as many examination passes as all the other schools in England put together. ${ }^{49}$ It achieved this enviable (and envied) record at a time (1870-1900) when half or more of the candidates regularly failed the Minor examination. ${ }^{50}$ In the Session 1876-77, for example, the numbers of successful Westminster entrants were 105 in the Major, Minor, and Modified examinations, 151 in the

with accuracy; the percentage of ash in certain drugs; the melting points of certain substances; and the solubilities of certain salts of the British pharmacopoeia.

${ }^{44}$ The case of Dr John Muter (1841-1911), the Principal of the South London School of Pharmacy (see note 63 below) was exceptional. He published between 1877 and 1900 fifteen memoirs on the analysis of foods, all of which appeared in the Analyst, of which he was a co-founder (1877) and co-editor (1877-91). The work was done in his capacity as Public Analyst for several South London boroughs and the County of Lincolnshire (see Royal Society Catalogue of Papers, 1874-83, 1884-1900, vols, ix, xiii. Obituary, Journal of the Chemical Society, 1912, 101: 691).

${ }^{45}$ Prospectus, 1901, op. cit, note 31, above, p. 24.

${ }^{46}$ Chemist and Druggist, 1908, 73: 940.

${ }^{47}$ Chemist and Druggist, 1912, 80: 506.

${ }^{48}$ Chemist and Druggist, 1916, 88: 343 . At that time, sixty-six Westminster men were serving in the armed forces (Chemist and Druggist, 1915, 87: 43).

${ }^{49}$ Prospectus, 1877, op. cit., note 31 above, p. 2.

${ }^{50}$ Holloway, op. cit., note 1 above, p. 405. 


\section{George S V Wills and Pharmaceutical Education in Great Britain}

Preliminary, and 187 in the Apothecaries' Hall's dispensers' examinations. ${ }^{51}$ A significant proportion had achieved this success by the College's postal system. When in the following year, 14 Major candidates presented themselves before the Board of Examiners, they secured a 100 per cent pass. ${ }^{52}$

Wills was well aware of the students' essential contribution to this overall success, and never tired of reminding them of their part in the mutual teaching and learning process:

The student's success depends more upon his own effort than upon anything else; neither teaching, textbook, lecture-room nor laboratory can do much for him, who will not do his utmost for himself. The best instruction and opportunities cannot make an idle or careless student successful, while on the other hand, to the diligent and hard-working, failure is well-nigh impossible. ${ }^{53}$

By 1900, after twenty-five years' steady exertion, 4000 chemists and druggists registered by the Pharmaceutical Society (out of a total of 16,000 nationwide) were alumni of Westminster College, more than 800 of them being established in their own businesses. ${ }^{54}$ They were to be found throughout Britain, as well as in far-flung parts of the Commonwealth, where the London qualification was recognized. Some 300 former students had entered the medical profession, and three opened schools of pharmacy of their own.

The success of the private pharmacy schools was watched by the Council of the Pharmaceutical Society with mounting reserve, as more and more students elected to attend the proprietary sector in preference to the schools approved by the Society. In 1880, the situation was closely analysed by John Attfield, the Society's professor of chemistry. ${ }^{55}$ In his memorandum, he contrasted a sound and systematic pharmaceutical education with the odious practice of the tutorial establishments that aimed at the mere "preparation of their candidates for passing examinations". This deplorable "cramming" approach, though admittedly effective and popular with the students, was likely to impart only superficial and transient knowledge. ${ }^{56}$ At the same time, Attfield admitted certain weaknesses in the Society's examination system, such as the imperfect correlation of the questioning with the material actually taught, as well as the examiners' difficulty of distinguishing between bona fide and "crammed" candidates.

Attfield therefore advocated that the preparation for the Minor examination should henceforth be a compulsory full-time course of study of at least five months' duration at an approved teaching establishment. His proposals commended themselves to senior members of the Society, as a file of 66 supporting letters, reprinted in his pamphlet,

\footnotetext{
${ }^{51}$ Publisher's 16-page Advertisement Section, bound with Wills's Vegetable materia medica, see Appendix, no. 8

${ }^{52}$ A souvenir, op. cit., note 31 above, p. 71.

${ }^{53}$ Prospectus 1901 , op. cit., note 31 above, p. 10.

${ }^{54}$ A souvenir, op. cit., note 31 above; Appendix: List of names and addresses of Westminster alumni conducting their own businesses.

${ }^{55} \mathrm{John}$ Attfield, A pamphlet on the relation to each other of education and examination, especially with regard to Pharmacy in Great Britain, London, M'Corquodale, 1880 (2nd ed. 1882). John Attfield (1835-1911), FRS, was trained in the Society's School, where he won first prize in all subjects (1854).
}

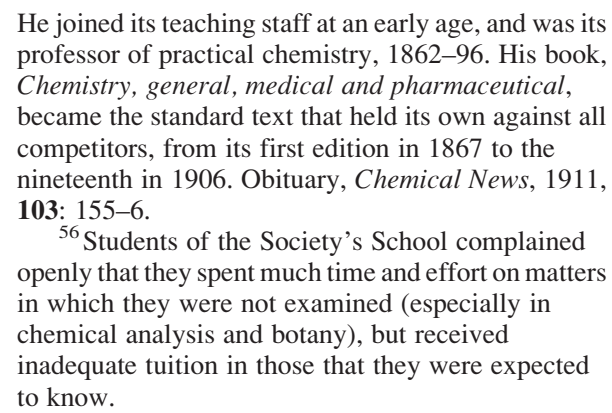

He joined its teaching staff at an early age, and was its professor of practical chemistry, 1862-96. His book, Chemistry, general, medical and pharmaceutical, became the standard text that held its own against all competitors, from its first edition in 1867 to the nineteenth in 1906. Obituary, Chemical News, 1911, 103: $155-6$.

${ }^{56}$ Students of the Society's School complained openly that they spent much time and effort on matters in which they were not examined (especially in chemical analysis and botany), but received inadequate tuition in those that they were expected to know. 


\section{Frederick Kurzer}

testified. Of these, 25 were signed by Council members, 26 by examiners past and present, and 15 by "other leaders in Pharmacy", including the Presidents of the Pharmaceutical Societies of Great Britain, and of Ireland, of the Chemists and Druggists' Trade Association, and of the Chemists' Assistants' Association. It was further insinuated that the new measures would favour entrants able to afford the cost of full-time study, thus leading to the recruitment of a greater proportion of candidates "from a superior class", ultimately raising the future standing of the profession, ${ }^{57}$ an illiberal attitude that greatly raised Wills's indignation.

It seems curious that Attfield and his supporters did not attempt to resolve their problem by simply reforming the examinations, which since their inception had been conducted orally by a panel of practising chemists of undoubted seniority but unspecified pedagogical credentials. ${ }^{58}$ A change to written papers would have replaced these often inadequate and unpredictable "interrogations" with a sounder, more academic procedure, allowing candidates to display their knowledge in an orderly and correct style that was so earnestly desired. Written qualifying examinations were not introduced until the 1920s.

When the Society submitted its proposals to Parliament as a Pharmacy Act Amendment Bill (1891), having previously several times failed to carry the point, Wills resolutely opposed it, both in its educational and social implications. In a closely argued memorandum addressed to Members of Parliament, who would be the ultimate arbiters, he showed how the proposed obligatory full-time study would close the profession to worthy young men unable to meet the increased expense. He insisted that it should matter little how and where a candidate had obtained his knowledge, provided he was duly qualified by having passed the prescribed examinations. He cited the current practice of the University of London, which conferred external degrees (including doctorates) solely on the basis of examination without reference to the student's scholastic record. As far as the charge of "cramming" was concerned, Wills had never ceased from urging his students to pursue their studies intelligently, with the desire of acquiring a sound and lasting knowledge as the equipment for a useful professional life. With help from other liberal influences, the Bill was eventually lost. Its intended changes were indeed implemented some thirty years later, but by then the greatly changed social conditions made their adoption acceptable.

By his general, liberal attitude and the spirited defence of his teaching methods, Wills did not endear himself to the inner circle of the Society. When he sought election to its Council, his candidature was actively opposed from that quarter: he failed to win a seat on at least four occasions between 1874 and $1913 .^{59}$ In the 1888 election, for example, when he canvassed the voters by a circular letter briefly setting out desirable policies, a caucus of four very senior members (the powerful names of William Martindale and of F Baden

\footnotetext{
${ }^{57}$ Editorial, Pharmaceutical Journal, 28 April 1888.

${ }^{58}$ In addition to the President and Vice-President ex officio, the Board of Examiners, as originally constituted in 1843 , consisted of eight "dispensing chemists", who originally gave their services free, hut later received a fee of 3 guineas per day. According to the list of the examiners who
}

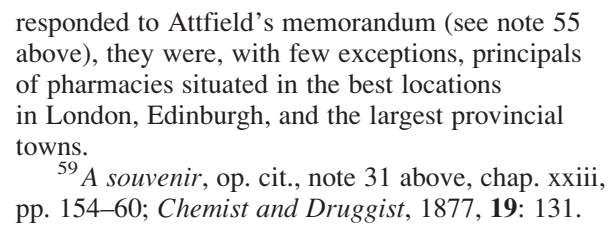

responded to Attfield's memorandum (see note 55 above), they were, with few exceptions, principals of pharmacies situated in the best locations in London, Edinburgh, and the largest provincial towns.

${ }^{59}$ A souvenir, op. cit., note 31 above, chap. xxiii, pp. 154-60; Chemist and Druggist, 1877, 19: 131. 
Benger amongst them), issued a counter-circular opposing his election in the most uncompromising terms. They contended that as a Councillor, he would have a voice in the appointment of the examiners, which for a "proprietor of an educational establishment conducted as a business" would be inappropriate, and hinted at other though unspecified ulterior motives. In his defeats, Wills was consoled by numerous messages of support from his wide circle of friends amongst the general membership.

\section{The College's Move to Clapham}

With the passage of the years, the Westminster College continued to enjoy everincreasing success and popularity. However, in 1908, financial disaster overtook its Principal which, though unrelated to College affairs, caused a temporary setback to its fortunes. Wills had, at the commitment of considerable capital, established a pharmacy business (1898) near his residence in South Croydon. Considering his heavy College duties, it is hardly conceivable that he contemplated conducting the business personally, but may have sponsored it for the benefit of a relative. Be this as it may, the venture was not a success and led to grave financial embarrassment. ${ }^{60}$ It resulted in the loss of Wills's house and personal assets, and necessitated the voluntary liquidation of Westminster College (which had been registered as a limited company in 1901), and its removal from the much-loved Trinity Street home. ${ }^{61}$ The disruption of College life during a few dark months was swiftly overcome. With customary energy Wills resumed its established programme at a new location in Clapham Road, Lambeth, a neighbourhood that was the venue of several pharmacy schools. ${ }^{62}$ With the arrival of Westminster College, this area of south London housed six institutions, which between them supplied the greater part of the privately trained pharmacists for the entire country. ${ }^{63}$ In the new location, teaching and laboratory work went on apace as before, evening classes were resumed and postal tuition expanded.

\footnotetext{
${ }^{60}$ Chemist and Druggist, 1908, 72: 632; 1909 , 74: 725, 775, 821-2; 1909, 75: 742.

${ }^{61}$ The building was occupied by the "Biopictureland Theatre" (giving "dioramic presentations", 1909-13), and later by the Trinity Cinema (1915-c.1940) (see Post Office Directory, Trinity Street, Southwark, 1880-1940). It was described as "derelict" in a survey of 1955 (Ida Darlington, 'St George's Fields', in Sir J R Howard Roberts (ed.), Survey of London, vol. 25, London County Council, 1955, p. 108). Today, its site, together with that of two former flanking town-houses, is taken up by an unprepossessing block of apartments. 75: 297.

${ }^{62}$ Chemist and Druggist, 1908, 73: 274; 1909 ,

${ }^{63}$ The instutions were: (1) The Westminster College of Chemistry and Pharmacy, 402 Clapham Road (from 1908; transferred to number 190 in 1919).
}

Both the buildings and their surroundings fell victim to air-attacks during the Second World War; they have entirely vanished, their sites being occupied by modern open-plan housing estates. (2) South of England College of Pharmacy, 186 Clapham Road; Principal: H Lucas, PhC, FCS. (3) London College of Chemistry, Pharmacy and Botany, 323 Clapham Road; Principals: Henry Wootton (Wills's former partner at Trinity Street, until 1898), and A Kirkland. (4) South London School of Pharmacy, 325 Kennington Road (Kennington Cross, adjoining Clapham Road); Principal: John Muter, MA, PhD, FCS, Public Analyst. (5) Brixton School of Chemistry and Pharmacy, 78 Stockwell Park Road; Principal: Dr A B Griffiths, FRSE. (6) London College of Pharmacy, 361 Clapham Road; Principal: Irvine G Rankin, BSc, PhC. 


\section{Frederick Kurzer}

The propinquity of the several pharmaceutical colleges to each other fostered their corporate spirit. A regular feature at Westminster College was the annual distribution of its prizes and certificates, which was combined with a musical evening or "smoking concert". The friendly, neighbourly relations between the Clapham establishments were reflected in joint social events. ${ }^{64}$ A dance held for three of the colleges in 1924, attended by some 200 students and their friends, was apparently the first time that ladies had been invited to a social event, a welcome contrast from the "separate classrooms and museum for women students" that had been advertised five years previously by the London College. ${ }^{65}$

\section{Westminster Correspondence Courses}

A most important activity of the College was its provision of correspondence courses which greatly increased its educational influence. The capacity of its premises for full-time students never exceeded approximately 150 persons. However, after only three years' operation it had currently "the names of 803 pupils on its books, and new ones were added daily", 66 showing clearly the heavy share of its part-time teaching and correspondence work.

"Wills' Universal Postal System", as its author styled his scheme, differed from the conventional practice of sending out lessons together with set work to be attempted and returned to the tutor for correction and comment. Wills's scheme merely directed the home study of his correspondents, who were required to monitor their progress by selfassessment. Being unfamiliar with the exact requirements of the examination syllabus, their chief need was guidance of their efforts into the right channels, a need which the scheme satisfied admirably (Figure 5).

Thus, Wills's subscriber received regular "lectures" in the form of a printed eight-page octavo pamphlet on one or other subject of the curriculum. The instalment was usually equivalent to a chapter of a conventional textbook, but was suitably condensed and edited to highlight its most salient points. The student was instructed to copy these lessons verbatim into a notebook, and thoroughly study, mark and digest the information. The printed pamphlet remained the property of the College and had to be returned by post before the next one was supplied. The College insisted on strict regularity of this routine: if the current lesson was not punctually returned, the student was fined ("6 stamps", presumably to the value of sixpence) and warned, "that he would miss the next instalment which could then only be supplied at the end of the course". ${ }^{67}$

In its austere simplicity, the Westminster postal scheme embodied advantages for College and student alike. Once the system was set up, it needed-apart from occasional up-dating - only care and accuracy of clerical staff for its maintenance. There was no upper limit to the number of students that could be accepted. The service could therefore be

\footnotetext{
${ }^{64}$ See, for example, Chemist and Druggist, 1910, 77: 838; 1911, 79: 464; 1914, 84: 480; 1921, 94: 224.

${ }^{65}$ Chemist and Druggist, 1924, 100: 533; 1918 , 90: 654 .

${ }^{66}$ Editorial, 'Pharmacy by post', Chemist and Druggist, 1877, 19: 116.
}

\footnotetext{
67 'Rules Applicable to Postal Courses', printed in the set of Major Lectures, 1877 (see Appendix, no. 21). Some of the more draconian regulations and fines appear to have been relaxed by 1900 (see Prospectus, 1901, op. cit., note 31 above, p. 84)
} 


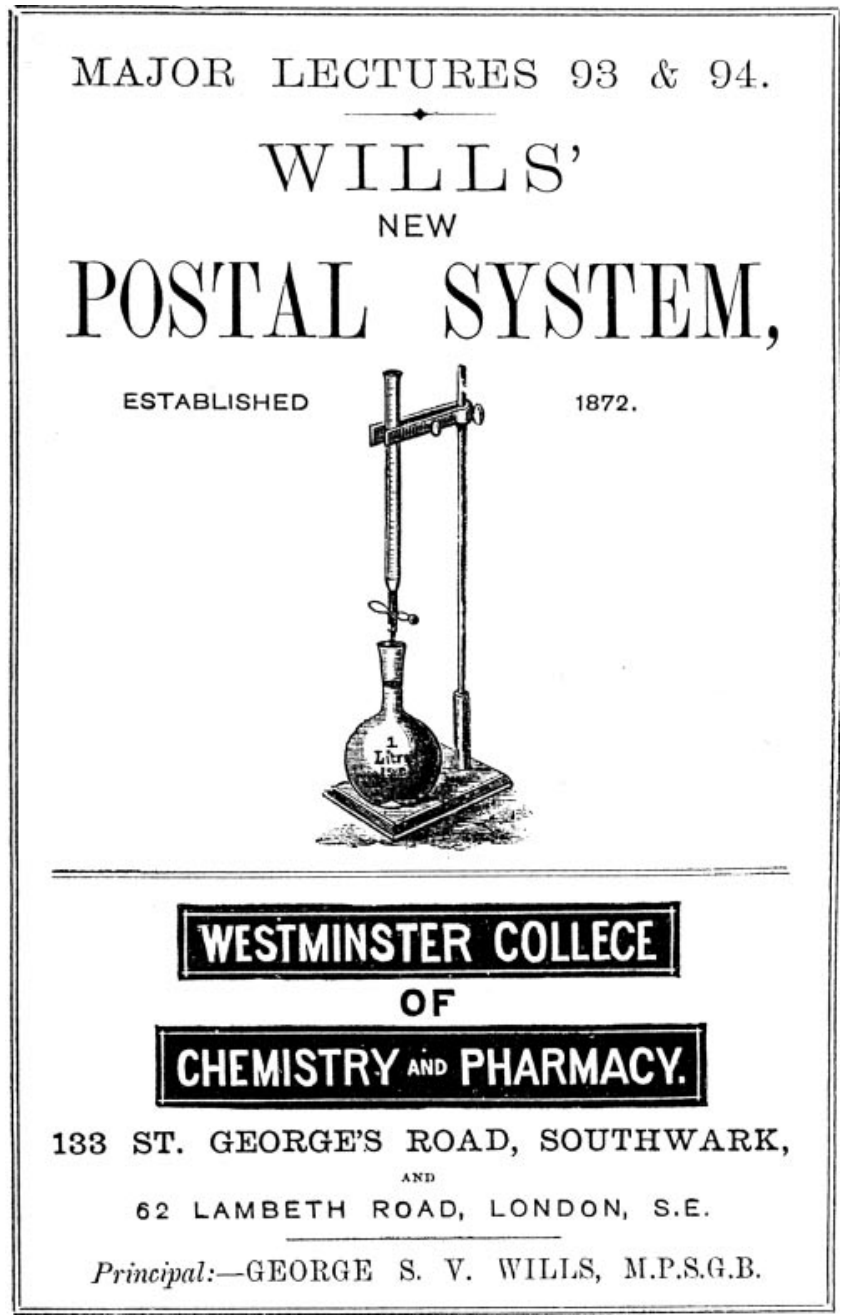

Figure 5: Wills' new postal system. Title-page of an instalment of the Major course (see Appendix, no. 21).

provided at an astonishingly low fee, a full course of 100 lessons sent in 50 instalments costing no more than one guinea. With the added trifling expense for postage spread over a year or more, access to Westminster postal tuition was indeed available to all.

The benefits to the student were equally obvious: he could commence the course at any time, and progress at a rate suitable to his circumstances. To the young apprentice or assistant remote from educational centres, the postal courses were a life-line indeed, which greatly raised his prospects of examination success. Such was the high reputation of this form of tuition that students frequently availed themselves of it before undergoing 


\section{Frederick Kurzer}

Table 1

Survey of lectures in Wills' Postal Courses. Number of lecture instalments

\begin{tabular}{|c|c|c|c|}
\hline & \multicolumn{2}{|c|}{ Minor } & \multirow{2}{*}{$\begin{array}{l}\text { Major } \\
1877^{\mathrm{a}}\end{array}$} \\
\hline & c. $1877^{\mathrm{a}}$ & $1901^{\mathrm{b}}$ & \\
\hline Chemistry & 26 & 30 & 40 \\
\hline Botany & 14 & 16 & 10 \\
\hline Pharmacy & 38 & 26 & 4 \\
\hline Materia medica & 8 & 10 & 34 \\
\hline Dispensing & 22 & 9 & - \\
\hline Physics & 8 & 4 & 4 \\
\hline Revision tests & 8 & 10 & 6 \\
\hline Total & 124 & 105 & 98 \\
\hline
\end{tabular}

${ }^{\mathrm{a} C}$ Compiled from complete sets of lectures held in the British Library. (See nos. 20 and 21 in Appendix.)

${ }^{\mathrm{b}}$ As advertised in the College Prospectus, 1901 (see note 31).

full-time study, which enabled them to reduce the time and expense of later College attendance. $^{68}$

The content of the postal courses, closely tuned to the official syllabus, is reflected in the number of lectures allotted to the individual subjects (Table 1). ${ }^{69}$ The revision testspapers issued at regular intervals-were a particularly useful feature; students received more than 500 specimen questions, providing much material for practice, and an insight into the prevailing examination culture.

For all the success of the postal system, Wills was aware of the desirability of imparting a finishing "gloss" on his examination entrants; he strongly advised them to attend College on a full-time basis for at least one month, for final intensive revision and perfection of their skill in chemical analysis and in the identification of materia medica. ${ }^{70}$ Additional help was at hand by the loan, for a fee of 2 guineas, of further teaching aids and specimens, chiefly concerned with the practical part of the work. The candidate was once again urged to master the contents of Wills's teaching manuals (see Appendix), with a hint that they provided all the necessary information without distracting him with superfluous matter, as the larger textbooks were liable to do.

The College also ran a popular postal course for candidates of the Preliminary examination of the Pharmaceutical Society, which served as the threshold to its professional examinations. ${ }^{71}$ This was a lower version of common university entrance, being confined to only three subjects, namely arithmetic, English and Latin. In terms of student passes, the

\footnotetext{
${ }^{68}$ Several press opinions had endorsed the postal system warmly at an early date, and Wills was not slow in quoting them in his Prospectuses. When he reprinted them time and time again, the Chemist and Druggist (1917, 89: 370) commented drily, "the College should affix dates to the opinions published regarding the postal courses".
}

\footnotetext{
${ }^{69}$ Wills' new postal system. Minor lectures (see Appendix, no. 20): Notice after Lesson 110/111. Major lectures (see Appendix, no. 21).

${ }^{70}$ The student was urged to do so promptly to avoid "losing much of the benefit of the study he has given to the various subjects".

${ }^{71}$ Wills' new postal system. Preliminary lectures (see Appendix, no. 19).
} 


\section{George S V Wills and Pharmaceutical Education in Great Britain}

course was apparently highly successful, but its intrinsic educational merit was not high. ${ }^{72}$ However, its manifest dreariness, especially in grammar and Latin, can hardly be blamed on the College, which covered the prescribed syllabus by the pedestrian approach in common use by all but the more enlightened schoolmasters of the day.

The tutorial activities of the Westminster College were part of a much wider educational network that prepared candidates for a variety of qualifying professional examinations. Postal tuition was particularly appropriate in subjects that required no provision of practical laboratory or workshop instruction, such as the law, accountancy or business studies. ${ }^{73}$ The firm of law tutors, Messrs Gibson \& Weldon, for example, had since the 1880 s prepared entrants to the Law Society's examination with conspicuous success, both in tutorial classes and by correspondence courses. Its Monthly Law Notes for Students presented legal topics instructive for pupils, and provided specimen answers to current examination papers (the latter policy being one which the Pharmaceutical Society disfavoured). ${ }^{74}$ The fee for a three months' intensive course was 15 guineas, that for the parallel weekly postal course, 6 guineas. ${ }^{75}$ Such was the high regard in which this commercial tutorial firm was held in the profession that it was acquired, in 1962, by the Law Society and amalgamated with its own long-established school to form its new College of Law, now one of the leading law schools of the country.

\section{The Closing Years}

With his extraordinary dedication, Wills remained in sole charge of his College up to the age of seventy-six. H P Woodnoth, MPS, who had for some years been a member of the teaching staff, and had become Wills's son-in-law, was taken into partnership in 1914, but did not take up his duties as Joint-Principal until after his return from war service in 1919. Wills continued in sole command, organized yet another move of the College (from 402 to 190 Clapham Road in December 1916), and bore the main burden of the lecturing load. He did not fully retire until 1927, when Woodnoth continued to guide the fortunes of the College for another fifteen years.

After the turn of the century an increasing share of pharmaceutical teaching passed to the public sector. The opening of new polytechnics and technical colleges, especially since the passing of the Technical Instruction Act of 1889, created new departments dedicated

\footnotetext{
${ }^{72}$ The course comprised 50 lessons in Latin, 16 in English, and 22 in arithmetic, with 12 model examination papers interspersed. Pupils had again to supervise their progress by self-assessment, aided by answers supplied to some of the questions in subsequent lessons.

${ }^{73}$ For a brief survey of tuition by correspondence, "a characteristic branch of Victorian educational industry", and assessment of its significance in widening access to professional qualifications, see Millerson., op. cit., note 8 above, pp. 140-1.

${ }^{74}$ Sugarman, op. cit., note 9 above, pp. 10, 12. Albert Gibson, Gibson's Law Notes: A Monthly
}

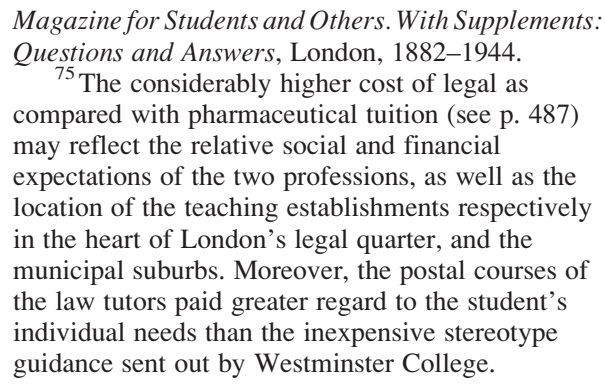




\section{Frederick Kurzer}

to the teaching of pharmacy. By 1899, approved courses were available in fifteen of the new technical schools, both in London (for example, at Chelsea Polytechnic from 1895) and the provinces. ${ }^{76}$

This expansion, though significant, was tested to the limit of its capacity at the close of the First World War. The return of demobilized servicemen, whose careers in pharmacy had been interrupted or postponed, created an unprecedented demand for training, leading to a sudden surge of some 4000 applicants for 500 available study places. The Pharmaceutical Society met the situation by accrediting yet more teaching centres, encouraging the enlargement of existing ones, and the setting up of temporary laboratories. ${ }^{77}$ The qualifying examination was reformed by the replacement of oral questioning by written papers, and by its division into two stages: Part I covered the basic sciences of chemistry, botany and physics, and Part II the professional components, including pharmacy, pharmaceutical chemistry, pharmacognosy, and forensic pharmacy. ${ }^{78}$

Once begun, the trend for expansion continued apace. By 1932, the Society's official list of recognized institutions had grown to seven centres in London, forty-three in the provinces, and six in Scotland. ${ }^{79}$ Henceforth, students were able to attend college nearer home; they often benefited by studying the basic sciences (especially chemistry) in the competent specialist departments maintained in the larger institutions. ${ }^{80}$

During the acute post-war shortage of training accommodation, the private pharmaceutical schools - the Westminster College foremost amongst them-had valiantly helped to fill the gap, and had indeed temporarily enjoyed increased prosperity and unaccustomed official approbation. However, the subsequent mounting competition from the public institutions militated powerfully against all but the most robust private schools, and their number declined as the demands in staffing and equipment for teaching an ever-expanding syllabus began to outstrip their resources. After 1932, the Pharmaceutical Society embarked on a deliberate programme aimed at closing the remaining survivors. Several provincial establishments were absorbed by local technical colleges (Bath, and Liverpool, for example) or universities (Manchester, Leeds). In London, the South of England College was acquired by purchase and closed down, and the London College ceased to exist when its Principal was appointed Secretary to the Society's Standing Committee.

The Westminster College, as one of the longest lasting survivors, advertised its courses as late as the 1930s and was still prominently featured in 1935 in a report and full-page pictorial display in the Chemist and Druggist showing "where Pharmacy is Taught"; two of the nine illustrations depicted its lecture room, and new physics laboratory. ${ }^{81}$ At the outbreak of the Second World War in 1939, the threat of air-attacks on London induced the

\footnotetext{
${ }^{76}$ Holloway, op. cit., note 1 above, p. 405.

${ }^{77}$ Matthews, op. cit., note 1, p. 165; 'Pharmacy schools filling up', Chemist and Druggist, 1919 , 91: 126,142

${ }^{78}$ Editorial, 'New examination regulations', Pharmaceutical Journal and Pharmacist, 1932, 128: 494-503.

79 'Teaching institutions', Chemist and Druggist, 1932, 117: 193-7.
}

\footnotetext{
${ }^{80} \mathrm{~A}$ chart showing the number of teaching institutions existing between 1880 and 1963 , classified into groups conducted by the Pharmaceutical Society, by private proprietors, by technical colleges, and by universities has been compiled by Earles (op. cit., note 2 above, p. 92).

${ }^{81}$ See, for example, Chemist and Druggist, 1932, 117: 193; 1933, 119: 259; 1935, 123: 197.
} 


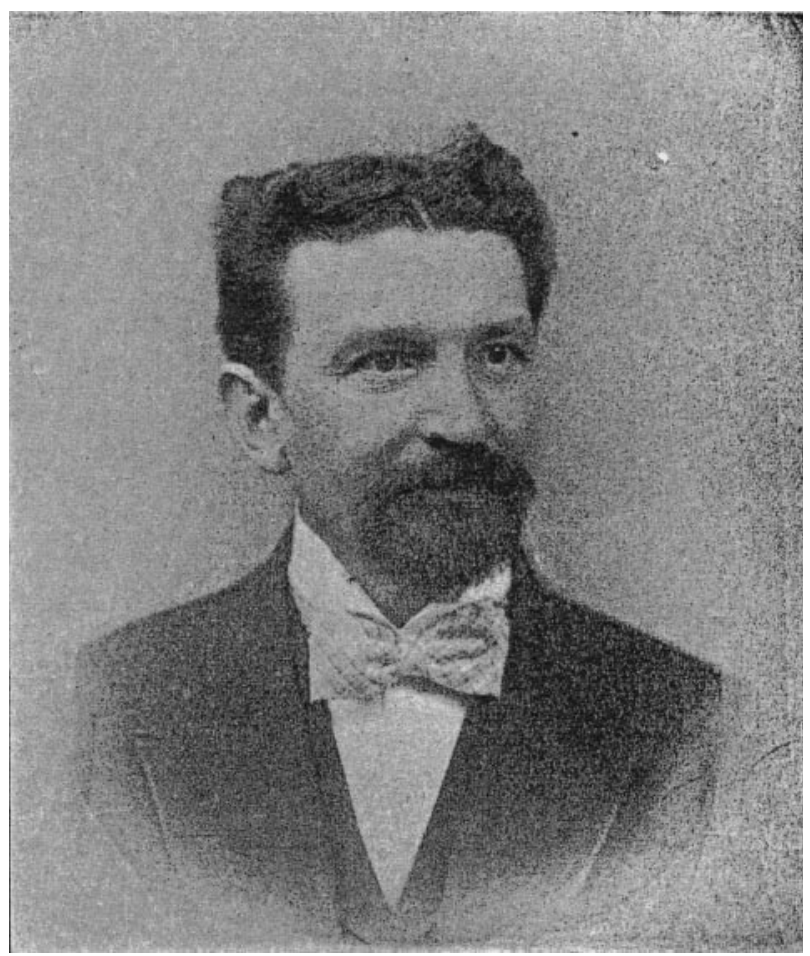

Figure 6: Portrait of George S V Wills, aged about fifty. From the Prospectus and syllabus of the Westminster College of Chemistry and Pharmacy, London, 1901.

College to discontinue its day classes in favour of correspondence courses, ${ }^{82}$ but this work was not destined to continue for long. The College address, 190 Clapham Road, regularly listed in the Post Office Directory, disappeared in 1942, which must be taken as the year of its demise. ${ }^{83}$

\section{George S V Wills}

It has been well stated that the success of the individual private schools of pharmacy depended ultimately on the abilities and personality of their principals, ${ }^{84}$ a proposition that could hardly be more apposite than in the case of George Wills. His talents as a teacher and administrator, coupled with a seemingly inexhaustible capacity for work, enabled him to

\footnotetext{
${ }^{82}$ Chemist and Druggist, 1939, 131: 197.

${ }^{83}$ Since the names of the occupiers of the adjacent houses, nos.186 and 192, were omitted from the Post Office Directory at the same time, it is probable that the immediate neighbourhood
}

was severely damaged or destroyed in the air-attacks on London.

${ }^{84}$ Centenary commemoration, op. cit., note 1 above, p. 12 . 


\section{Frederick Kurzer}

superintend the complex enterprise he had created as a young man with apparent ease that did not diminish with the advancing years (Figure 6).

Wills was a gifted speaker who could, at a moment's notice, propose a graceful vote of thanks, deliver an amusing after-dinner speech, or take part effectively in a debate. He had the happy facility of enlivening apparently abstruse topics with anecdote or apt quotation that was appreciated by lay audiences no less than by his Westminster students. A former pupil of the last class that had been personally supervised by Wills testified to the "magnetism of his personality and the brilliance of his performance" as a lecturer, at a time when he had passed the age of seventy-five. ${ }^{85}$

Wills was the author of some two dozen textbooks and manuals that covered the full range of the pharmaceutical syllabus (see Appendix). They appeared originally in quick succession under the imprint of Westminster College to aid his own students, but attracting favourable reviews, enjoyed wide circulation. All these manuals were moderately priced so as to be within the reach of all students.

As a competent analyst, Wills was able to offer his services for the chemical and microscopical examination of water, foodstuffs and drugs, as well as manures, soils, minerals and ores. During a typhus epidemic in Stony Stratford, the scene of his youth, he traced its cause to the gross contamination of its water supply, with the exception of one spring some distance from the town. With this information, the community avoided further infection, and installed, on Wills's advice, a simple water purification plant that prevented future water-borne disease. When Wills revisited on this occasion his small home town, and delivered a popular lecture 'On Water', the local people, proud of their son's success in the big city, flocked from far and wide to hear him speak. ${ }^{86}$

It is evident that Wills loved a challenge, and when embarked on a contest liked to be on the winning side. He delighted, through the success of his students, to hold his own before the formidable Board of Examiners year after year, and was no less bold in unfamiliar fields. An extraordinary feat was his winning an open competition set by a popular magazine, which offered a prize of $£ 5$ for the closest estimate of the number of persons walking over London Bridge during twenty-four hours on 23 January $1889 .{ }^{87}$ Of the 36,000 entries received, Wills's figure, 111,870, coincided almost miraculously with the one $(111,873)$ returned by the official team of "enumerators" who had been posted in relays on the bridge throughout the twenty-four hours. When general disbelief at the marvel was voiced, Wills disclosed his simple statistical method: he had counted 15-minute samples at various times, and calculated his figure directly from these data. ${ }^{88}$

\footnotetext{
${ }^{85}$ F W Chapman, 'The late G S V Wills', Pharmaceutical Journal and Pharmacist, 1932, 128: 408.

${ }^{86}$ A souvenir, op. cit., note 31 above, p. 189.

${ }^{87}$ Answers to Correspondents on Every Subject under the Sun, No. 1-82 (1888-89); continued as Answers, No. 83-3311 (1889-1955); continued as
}

\author{
Answers and TV Pic, No. 3312-3329 (1955-56) \\ then discontinued. London Bridge was regarded as \\ "the most crowded bridge in the world", as City \\ workers used it twice daily in crossing the river \\ between their offices and London Bridge railway \\ station on the south bank. \\ ${ }^{88}$ A souvenir, op. cit., note 31 above, p. 183.
}




\section{George S V Wills and Pharmaceutical Education in Great Britain}

He showed his competitive spirit in other ways: although personally indifferent to sport and athletics, he participated on the spur of the moment at one of the College's friendly sporting events in the race for veterans, which he promptly won. ${ }^{89}$ As ex officio President of the College's Football and Cricket Clubs, he paid half the fee of the hire of the ground for the football fixtures, but characteristically met the full cost if his Westminster team won the game.

Not surprisingly, the students held their popular Principal and champion in high regard and affection. They regularly celebrated his birthday on St Valentine's Day by a social event, at which they presented him with an illuminated address and occasional present such as Watt's Dictionary of Chemistry, or a silver coffee pot, subscribed from their meagre allowance, as clear tokens of their loyalty. ${ }^{90}$ These sentiments endured long after the students had left the College, and had settled in business or responsible positions in all parts of the kingdom and far away places of the then British overseas territories. When in 1922, Wills accompanied by his wife and married daughter spent a holiday in South Africa (which included an adventurous overland trip of some 300 miles by motor car from Johannesburg to the port of Durban), he was welcomed there by several of his former students, who were delighted to extend to their teacher and his party every assistance and hospitality. ${ }^{91}$

Wills was a man of firm religious conviction. In his early Lambeth days, he was a prominent member of the local Baptist Upton Chapel, where he was elected (1881) VicePresident of its Tract Society and a deacon (1885). He formed a lasting friendship with its minister, the Rev. William Williams, himself an author and particular friend of the renowned preacher C H Spurgeon. ${ }^{92}$ After his move to South Croydon (1888), Wills felt the want of a religious focus for the local Baptist community, and helped to establish a chapel in their locality, personally acquiring the freehold of the land on which it was eventually built. $^{93}$

Wills's long life was blessed with a happy marriage, the golden anniversary of which he celebrated on 30 September 1924 in the circle of his family, including his five adult children. It nearly coincided with the fiftieth jubilee of the opening of the College in early October 1874. Except for his South Croydon period (1888-1906), Wills lived with his family in inner London boroughs south of the river, moving house several times, but invariably remaining within easy reach of his College. ${ }^{94} \mathrm{He}$ died at 5 Lessor Avenue,

\footnotetext{
${ }^{89}$ Chemist and Druggist, 1913, 83: 235.

${ }^{90}$ Some of these occasions were combined with an excursion to the Botanic Gardens at Kew. Although mid-February hardly seems a time for botanizing, the famous conservatories, both temperate and tropical, provided more than sufficient scope for botanical studies, and trips were rounded off by a celebration at the adjacent Rose and Crown Hotel, where the students were their Principal's guests.

${ }^{91}$ Chemist and Druggist, $1922,96: 738$.

${ }^{92}$ Charles Haddon Spurgeon (1824-1892), famed minister and preacher, regularly attracted
}

audiences that filled to overflowing Exeter Hall, and later (1861) the Metropolitan Tabernacle (with its capacity for 6000 persons), where he ministered until his death.

${ }^{93}$ A souvenir, op. cit., note 31 above, pp. 167-80.

${ }^{94}$ In South Croydon, Wills's house in Croham Road was only a short walk from the railway station, 11 miles from London Bridge Station, itself close by the College in Trinity Street. The daily commuting thus presented no problem. 


\section{Frederick Kurzer}

Clapham Park on 28 April 1932 in his eighty-fourth year and was buried in Kensal Green Cemetery. ${ }^{95}$

\section{Conclusion}

The present account of the history of the Westminster College of Pharmacy leaves no doubt that in its time- - together with its sister institutions-it made a substantial and honourable contribution to pharmaceutical education in Britain. As the leading institution of its kind in London, its record illustrates most completely the role of private establishments that helped to provide the qualified pharmaceutical personnel that the nation required. In retrospect, even the Pharmaceutical Society, which had been no friend of the private colleges, commended their efforts, admitting that they had "served their craft in their time faithfully, and many generations of pharmacists were their debtors". 96 Wills's Westminster College was singled out by name as their largest and most productive representative. ${ }^{97}$

Since Wills's days, both the study and practice of pharmacy have undergone profound changes. The qualifying course became ever more demanding and university-orientated, as scientific progress refined the traditional subjects, and as raised academic requirements added new ones (including physiology, pharmacology and biochemistry) to the syllabus. ${ }^{98}$ Glasgow was the first to introduce a BSc (Pharm) degree recognized by the Pharmaceutical Society (1919); London followed in 1924 with a two-year General BPharm degree, conferred in the Faculty of Medicine, and extended in 1946 to a three-year Honours degree. As other British universities followed suit, the curriculum gradually crystallized around the four principal disciplines of pharmaceutics, pharmaceutical chemistry, pharmacognosy and pharmacology, supported by several subsidiary subjects. In 1967, when the holding of a pharmacy degree was made an essential condition for professional registration, the Pharmaceutical Society discontinued its examining function, but retained its power of approving degree courses, and of imposing additional prescribed vocational experience prior to registration. ${ }^{99}$ A four-year Master's qualification (MPharm, conferred as a first degree) has recently made its appearance. The

\footnotetext{
${ }^{95}$ Anon., 'Obituary: G S V Wills', The

Pharmaceutical Journal and Pharmacist, 1932,

128: 386; anon., Obituary, Chemist and Druggist,

1932, 116: 624; details of his will, ibid., p. 672. This is

a very brief announcement by the chairman of the

Council of the Pharmaceutical Society at its meeting of 1 June 1932, who referred to the greater number of students who had been trained by MrWills than by any other proprietor of such an institution, and thought that he would be especially remembered for his genial personality.

${ }^{96}$ Centenary commemoration, op. cit., note 1 above, p. 12 .

${ }^{97}$ Holloway, op. cit., note 1 above, p. 403.

${ }^{98}$ Melvin Earles, 'The development of pharmaceutical education', in Anderson (ed.), op. cit., note 1 above, pp. 97-114, esp. pp. 104-5.
}

\footnotetext{
${ }^{99}$ These developments brought the education of the pharmacist in Britain in line with that prevailing in Continental Europe, where the "pharmacien" in France and "Apotheker" in Holland and Germany were university-trained. There the licensed pharmacies were restricted to supplying exclusively medicines and surgical products. See J D C Anderson, 'Pharmaceutical education in Europe', Chemist and Druggist, 1958, 170: 173-4; Alois Kernbauer, Zwischen Zunft und Wissenschaft. Der oesterreichische Apotheker- und Pharmazeutenstand in der Krise. Von der Mitte des 19. Jahrhunderts bis in das Jahr 1922, Geschichte der pharmazeutischen Ausbildung, Graz, Akademische Druck und Verlagsgesellschaft, 1989, pp. 372-80. The latter gives a useful comparison of the educational system in Britain and Continental countries.
} 


\section{George S V Wills and Pharmaceutical Education in Great Britain}

future of the teaching of pharmacy continues to be of close concern to the profession, and remains a subject of serious debate. ${ }^{100}$

During this period of educational reform, the functions of the graduate pharmacist have changed significantly in emphasis and direction. The art of compounding and dispensing medicines, and the expertise on traditional materia medica - the long-established hallmark of the proficient pharmacist - lost much of their relevance as up-to-date clinical practice has come to rely increasingly on the use of modern synthetic drugs of specific activity and application. ${ }^{101}$ Being provided by the manufacturers in a pre-packed form ready for immediate dispensing, be it as tablets, capsules, etc., they require no further skilled preparative intervention on the part of the pharmacist other than the responsible supervision of their correct supply.

Although the professional scope of the local pharmacist has in this sense narrowed, each of the estimated 30,000 community outlets in Britain requires the presence of at least one registered member of the profession, who is responsible for its conduct under the law. Thus, the retail distribution of medicines continues to employ the largest fraction of the qualified profession, though largely in a managerial rather than proprietary capacity.

Professional opportunities have widened elsewhere. Increasing numbers of pharmacists are finding careers in hospital dispensaries. Between 1953 and 1985, the number of persons so employed in Britain rose from 1500 to 4000 (from 7 per cent to 16 per cent of all working pharmacists). Recent years have also witnessed the emergence of the clinical pharmacist as a senior member of the modern professional health team. Attached to a hospital, or in a visiting capacity to medical community practices, he or she plays an advisory and consulting role, providing specialist information and guidance on all questions concerning the effectiveness, choice, safety, storage and disposal of drugs and surgical materials. Such expert support has become increasingly desirable in the appraisal and surveillance of the new remedies constantly generated by current research. ${ }^{102}$

Rewarding careers have also become available in the pharmaceutical industry, whose powerful multinational corporations maintain, with prodigious financial investment, the momentum of contemporary drug discovery. Its massive research and development programmes require the services of qualified specialists of every branch of the chemical, biological and medical sciences. With their many-sided training, pharmacists are well placed to contribute to any particular aspect of these research efforts. ${ }^{103}$

Brief reference must finally be made to the independent, privately owned pharmacies' diminishing share of trade as a result of aggressive competition by the multiple firms whose numerous retail outlets cover the country. Their centralized manufacturing facilities, their

\footnotetext{
${ }^{100}$ See, for example, Editorial, 'Is pharmacy education in crisis, or is it simply changing?', Pharmaceutical Journal, 2003, 271: pp. 790-1.

${ }^{101}$ Viviane Quirke, 'From alkaloids to gene therapy: a brief history of drug discovery in the 20th century', in Anderson (ed.), op. cit., note 1 above, pp. 177-202.
}

\footnotetext{
${ }^{102}$ Shirley Ellis, 'The development of pharmacy in hospitals', in Anderson (ed.), op. cit., note 1 above, pp. 135-54.

${ }^{103}$ Judy Slinn, 'The development of the pharmaceutical industry', in Anderson (ed.), op. cit., note 1 above, pp. 155-76.
} 


\section{Frederick Kurzer}

large-scale purchasing power and sheer financial strength have enabled them to set up branches in any prominent locality, and offer the public pharmaceutical services and a greater choice of products at lower prices than the independent pharmacy could hope to match. ${ }^{104}$ Attempts by the Pharmaceutical Society to curb such monopolies, and to prohibit the sale of medical products by customers' unsupervised self-service-a practice that had started in 1952-by appeals to the courts of law, all ended in expensive failure. Developments such as these contributed to the tendency of the majority of community pharmacists working as employees or managers rather than their own masters.

The metamorphosis of the chemist and druggist's apprentice to the university-educated pharmacist-scientist over the span of more than a century has raised pharmacy to a level amongst the professions with which Jacob Bell and his co-founders of the Pharmaceutical Society-its title dignified in 1988 by the "Royal" prefix—would have been well satisfied. The private schools of pharmacy, as represented by Westminster College under the inspired leadership of its Principal George S V Wills, played their own role in this evolution, and their merits deserve due recognition and a permanent place in the annals of pharmacy.

\section{Appendix \\ Wills's Manuals of Pharmaceutical Sciences}

This list specifies individual, or earliest and latest accessible editions of the books. Publication dates in square brackets are estimates as given in the British Library catalogue.

1. A manual of chemistry, London, Simpkin, Marshall, 1902.

2. A manual of practical analysis, London, Westminster College of Chemistry and Pharmacy, [1878]; 11th ed., London, Simpkin, Marshall, Hamilton, Kent, [1901].

3. Volumetric analysis, London, Simpkin, Marshall, [1892]; 2nd ed., London, [1901].

\footnotetext{
${ }^{104}$ A chain of chemist shops prominent in Britain has long been the firm of Boots the Chemists, built up since 1877 by Jesse Boot, ultimately from his father's modest herbalist store in Nottingham. By his extraordinary business acumen and enterprise, Boot rapidly increased the number of his branches to 181 by 1900 , to 560 by 1914 , and opened his thousandth shop in 1933. The acquisition of a rival multiple firm (Timothy Whites \& Taylor) in 1968 added at one stroke another 622 outlets to the Boots empire. Many of its larger branches were purpose-built chemists' emporia, occupying the most prominent commercial sites of town-centres. The whole enterprise was backed by the
}

ample manufacturing capacity of the firm's own factories at Nottingham, supplying its own requirements and supporting a substantial wholesale trade. However, its premier position has in recent years been encroached by rival chains and supermarkets. See Stanley D Chapman, Jesse Boot of Boots the Chemists: a study in business history, London, Hodder and Stoughton, 1974; Christopher Weir, Jesse Boot of Nottingham: founder of the Boots Company, Nottingham, Boots Company, 1994; Kathryn A Morrison, English shops and shopping: an architectural history, Newhaven and London, Yale University Press, 2003, pp. 209-19. 
George S V Wills and Pharmaceutical Education in Great Britain

4. Wills' botanical dictionary, reported "in the press" in the advertisement section of no. 8 below.

5. Companion to practical botany (text), London, Westminster College of Chemistry and Pharmacy, [1882]; The Westminster College series of botanical plates, illustrating the natural orders (advertised in Minor lectures, no. 20 below, at the end of Lecture 10).

6. Vegetable histology, London Simpkin, Marshall, [1906]; 3rd ed. London, P H Woodnoth, [1928].

7. A synopsis of organic materia medica, London, Simpkin, Marshall, [1901].

8. A manual of vegetable materia medica, with plates of 100 (hand-coloured) illustrations, London, Simpkin, Marshall, 1877; 4th enlarged ed., 1878.

9. Wills' book of dried medicinal specimens, arranged on the basis of the new schedule, advertised in the College Prospectus of 1901, see note 31 above.

10. Elements of pharmacy, designed as a textbook for students preparing for the Pharmaceutical Minor Examination, London, Simpkin, Marshall, [1877]; 9th ed. [1899].

11. Wills' book of autograph prescriptions; Key to ditto; Wills' guide to prescription reading. All three books advertised in the College Prospectus of 1901, see note 31 above.

12. Wills' prescripta. Containing 150 difficult prescriptions for dispensing, all of which have been given in the Minor Examination. Advertised in the College Prospectus of 1901, see note 31 above.

13. Doses of the British pharmacopoeia 1898, London, Westminster College [of Chemistry and Pharmacy], 1899; 20th ed. revised by P H Woodnoth, 1938.

14. Wills' manual of decimals, the metric system, and physics, London, Westminster College of Chemistry and Pharmacy, [1877].

15. Practical physics and specific gravity, with key, London, Westminister College of Chemistry and Pharmacy, [1900]; another ed. [1917].

16. A skeleton Latin grammar, advertised in the College Prospectus of 1901, see note 31 above.

17. Caesar's commentaries book I, fully parsed (published in parts, price 6 pence; when complete may be had bound, price 5s.). Announced in advertisements in Vegetable materia medica of 1877 (see no. 8 above). It is doubtful if this book was, in fact, completed.

18. Wills' preliminary exercises for the use of candidates preparing for examination, consisting entirely of questions set at the Preliminary Examination from 1870 to 1877, with answers and essays, London, Westminster College of Chemistry and Pharmacy, [1877]. 


\section{Frederick Kurzer}

19. Will' new postal system. Preliminary lectures 1-100, London, Westminster College of Chemistry and Pharmacy, [1877].

20. Will' new postal system. Minor lectures 1-124, London, Westminster College of Chemistry and Pharmacy, [1876-77]; another set [1879-80].

21. Wills' new postal system. Major lectures 7-106, London, Westminster College of Chemistry and Pharmacy, [1877]. 